\title{
Sphingobacterium daejeonense sp. nov., isolated from a compost sample
}

\author{
Correspondence \\ Wan-Taek Im \\ wandra@kaist.ac.kr
}

\author{
Kyoung-Ho Kim, ${ }^{1}$ Leonid N. Ten, ${ }^{1,2}$ Qing-Mei Liu, ${ }^{1}$ Wan-Taek Im $^{1}$ \\ and Sung-Taik Lee ${ }^{1}$ \\ 'Department of Biological Sciences, Korea Advanced Institute of Science and Technology, \\ 373-1, Guseong-dong, Yuseong-gu, Daejeon 305-701, Republic of Korea \\ ${ }^{2}$ National University of Uzbekistan, Students town, Tashkent, 700-174, Uzbekistan
}

A Gram-negative, strictly aerobic, rod-shaped, non-motile, non-spore-forming bacterial strain, designated TR6- $04^{\top}$, was isolated from compost and characterized taxonomically by using a polyphasic approach. The organism grew optimally at $30^{\circ} \mathrm{C}$ and at $\mathrm{pH} 6 \cdot 5-7 \cdot 0$. The isolate was positive for catalase and oxidase tests but negative for gelatinase, indole and $\mathrm{H}_{2} \mathrm{~S}$ production. Comparative 16S rRNA gene sequence analysis showed that strain TR6- $04^{\top}$ fell within the radiation of the cluster comprising Sphingobacterium species and clustered with Sphingobacterium mizutaii ATCC $33299^{\top}$ ( $96 \cdot 7 \%$ sequence similarity); the similarity to sequences of other species within the family Sphingobacteriaceae was less than $92.0 \%$. The $\mathrm{G}+\mathrm{C}$ content of the genomic DNA was $38.7 \mathrm{~mol} \%$. The predominant respiratory quinone was MK-7. The major fatty acids were iso- $\mathrm{C}_{15: 0}$, iso- $\mathrm{C}_{17: 0} 3-\mathrm{OH}$ and summed feature 4 (iso- $\mathrm{C}_{15: 0}$ 2-OH and/or $\mathrm{C}_{16: 1} \omega 7 \mathrm{c}$ ). These chemotaxonomic data supported the affiliation of strain TR6-04 ${ }^{\top}$ to the genus Sphingobacterium. However, on the basis of its phenotypic properties and phylogenetic distinctiveness, strain TR6-04 ${ }^{\top}\left(=\right.$ KCTC $12579^{\top}=$ LMG $23402^{\top}=$ CCUG $\left.52468^{\top}\right)$ should be classified as the type strain of a novel species, for which the name Sphingobacterium daejeonense sp. nov. is proposed.
The genus Sphingobacterium was created by Yabuuchi et al. (1983), who reclassified two former Flavobacterium species (Holmes et al., 1981, 1982) as Sphingobacterium multivorum and Sphingobacterium spiritivorum and proposed a novel species, Sphingobacterium mizutae [Holmes et al. (1988) corrected the spelling of the specific epithet to mizutai]. At present, the genus Sphingobacterium also includes three other species, Sphingobacterium antarcticum (Shivaji et al., 1992) [the original spelling of the specific epithet, antarcticus, was corrected by Euzéby (1998)], Sphingobacterium thalpophilum (previously classified as Flavobacterium thatpophilum) and Sphingobacterium faecium (Takeuchi \& Yokota, 1992). Two other previously described species, [Sphingobacterium] heparinum and [Sphingobacterium] piscium (Takeuchi \& Yokota, 1992), were reclassified in the genus Pedobacter (Steyn et al., 1998). Sphingobacterium species have been isolated from Antarctic soil and from clinical specimens, including blood, urine and the uteruses of human patients with opportunistic infections (Holmes et al., 1982; Yabuuchi et al., 1983; Shivaji et al., 1992). Members of the genus are Gram-negative rods that are positive for catalase and oxidase, negative for heparinase, gelatinase and indole production and contain iso- $\mathrm{C}_{15: 0}$,

The GenBank/EMBL/DDBJ accession number for the 16S rRNA gene sequence of strain TR6- $04^{\top}$ is $A B 249372$. iso- $\mathrm{C}_{15: 0} 2-\mathrm{OH}, \mathrm{C}_{16: 1} \omega 7 c$ and $\mathrm{C}_{17: 0} 3-\mathrm{OH}$ as the main fatty acids (Takeuchi \& Yokota, 1992; Steyn et al., 1998).

In this study, we have characterized an aerobic, non-sporeforming strain, TR6-04 ${ }^{\mathrm{T}}$, isolated from compost. Phenotypic, chemotaxonomic and phylogenetic analyses establish the affiliation of the isolate to the genus Sphingobacterium. The data obtained also suggest that the isolate represents a novel species of the genus.

Strain TR6- $04^{\mathrm{T}}$ was originally isolated from compost composed of cow dung and rice straw which was collected near Daejeon city in South Korea. This compost sample was thoroughly suspended in $50 \mathrm{mM}$ phosphate buffer ( $\mathrm{pH} 7 \cdot 0$ ) and the suspension, following serial dilution, was spread onto R2A agar (Difco) plates. The plates were incubated at $30^{\circ} \mathrm{C}$ for 3 weeks. Single colonies on the plates were purified by transferring them onto new plates. The purified colonies were tentatively identified by analysis of partial $16 \mathrm{~S}$ rRNA gene sequences. Strain TR6- $04^{\mathrm{T}}$ was one of the isolates that predominated on the R2A agar plates under aerobic conditions. Strain TR6- $04^{\mathrm{T}}$ was routinely cultured on R2A agar at $30^{\circ} \mathrm{C}$ and maintained as a glycerol suspension $(20 \%$, w/v $)$ at $-70{ }^{\circ} \mathrm{C}$.

A nearly complete $16 \mathrm{~S}$ rRNA gene sequence of strain TR6$04^{\mathrm{T}}$ was determined as follows. DNA was extracted using 
a commercial genomic DNA extraction kit (Core Biosystem) and amplification of the $16 \mathrm{~S}$ rRNA gene by PCR and sequencing of purified PCR product were carried out according to Kim et al. (2005). Partial $16 \mathrm{~S}$ rRNA gene sequences were assembled using SeqMan software (DNASTAR). The 16S rRNA gene sequences of related taxa were obtained from the GenBank database. Multiple alignments were performed using the CLUSTAL_X program (Thompson et al., 1997). Gaps were edited in BioEdit (Hall, 1999). Evolutionary distances were calculated using the Kimura two-parameter model (Kimura, 1983). Phylogenetic trees were constructed by using the neighbourjoining method (Saitou \& Nei, 1987) and the maximumparsimony method (Fitch, 1972) using the MEGA3 program (Kumar et al., 2004) with bootstrap values based on 1000 replications (Felsenstein, 1985).

The 16S rRNA gene sequence of strain TR6- $04^{\mathrm{T}}$ was a continuous stretch of $1472 \mathrm{bp}$. Comparative 16S rRNA gene sequence analyses showed that strain TR6- $04^{\mathrm{T}}$ is phylogenetically affiliated to the genus Sphingobacterium. The phylogenetic tree based on the neighbour-joining algorithm showed that strain TR6- $04^{\mathrm{T}}$ fell within the radiation of the cluster comprising Sphingobacterium species and joined Sphingobacterium mizutaii ATCC $33299^{\mathrm{T}}$ (96.7\% similarity) with a bootstrap resampling value of $100 \%$ (Fig. 1). Strain TR6- $04^{\mathrm{T}}$ exhibited less than $92 \cdot 0 \% 16 \mathrm{~S}$ rRNA gene sequence similarity with respect to the type strains of other recognized Sphingobacterium species. The phylogenetic definition of a species generally includes strains with approximately $70 \%$ or greater DNA-DNA relatedness (Wayne et al., 1987). According to the available compilation of data, organisms that have less than $97 \cdot 0 \% 16 \mathrm{~S}$ rRNA gene sequence similarity will not reassociate to more than $60 \%$, irrespective of the hybridization method applied (Stackebrandt \& Goebel, 1994; Keswani \& Whitman, 2001). This phylogenetic result demonstrated that strain TR6- $04^{\mathrm{T}}$ was not related to any of the previously described Sphingobacterium taxa at the species level.

A 16S rRNA gene sequence of the type strain of $S$. antarcticum was not available. Instead, we noticed a $16 \mathrm{~S}$ rRNA gene sequence from $S$. antarcticum strain $6 \mathrm{~B} 1 \mathrm{Y}$ (strain 6BY in the original paper of Shivaji et al., 1992), which had shown $100 \%$ DNA-DNA relatedness with strain $4 \mathrm{BY}^{\mathrm{T}}$, the type strain of $S$. antarcticum (Shivaji et al., 1992; S. Shivaji, personal communication). Thus this sequence can represent the species $S$. antarcticum. However, neighbour-joining trees showed that strain 6B1Y clustered in the genus Pedobacter and showed close affiliation with Pedobacter piscium DSM $11725^{\mathrm{T}}$ (Fig. 1). Strain $6 \mathrm{~B} 1 \mathrm{Y}$ and $P$. piscium DSM $11725^{\mathrm{T}}$ showed high $16 \mathrm{~S}$ rRNA gene sequence similarity $(99.9 \%)$ in a pairwise comparison. The $16 \mathrm{~S}$ rRNA gene of strain $6 \mathrm{~B} 1 \mathrm{Y}$ was sequenced only after the original description of the genus Pedobacter was published. Taxonomic rearrangement is required for this species.

The Gram reaction was performed by the non-staining method as described by Buck (1982). Cell morphology was observed under a Nikon light microscope at $\times 1000$, with cells grown for 3 days at $30^{\circ} \mathrm{C}$ on R2A agar. Catalase activity was determined by bubble production in $3 \%(\mathrm{v} / \mathrm{v})$ $\mathrm{H}_{2} \mathrm{O}_{2}$ and oxidase activity was determined using $1 \%(\mathrm{w} / \mathrm{v})$ tetramethyl $p$-phenylenediamine. For single-carbon-source assimilation studies, a defined liquid medium containing basal salts was used $\left(1^{-1}\right): \mathrm{K}_{2} \mathrm{HPO}_{4} 1 \cdot 8 \mathrm{~g}, \mathrm{KH}_{2} \mathrm{PO}_{4} 1.08 \mathrm{~g}$, $\mathrm{NaNO}_{3} 0.5 \mathrm{~g}, \mathrm{NH}_{4} \mathrm{Cl} 0.5 \mathrm{~g}, \mathrm{KCl} 0.1 \mathrm{~g}, \mathrm{MgSO}_{4} 0.1 \mathrm{~g}, \mathrm{CaCl}_{2}$ $0.05 \mathrm{~g}$. To this medium, a vitamin solution (Widdel \& Bak, 1992), trace element solution SL-10 (Widdel et al., 1983) and selenite/tungstate solution (Tschech \& Pfennig, 1984) were added and the $\mathrm{pH}$ of the medium was adjusted to $6 \cdot 8$. This liquid medium was aliquotted into 96-well trays and filter-sterilized carbon sources were added into each well (individually at $0 \cdot 1 \% \mathrm{w} / \mathrm{v}$ ). The plates were incubated at $30^{\circ} \mathrm{C}$ for 7 days and growth in was examined visually. A negative control well did not contain an added carbon source, and a positive control well contained R2A broth. Some physiological characteristics were determined with API 20E galleries according to the instructions of the manufacturer (bioMérieux). Anaerobic growth was examined in serum bottles with sodium thioglycolate $\left(1 \mathrm{~g} \mathrm{l}^{-1}\right)$ added to R2A broth and the upper air layer replaced with nitrogen gas. For examination of the reduction of nitrate as the final electron acceptor under anaerobic conditions, $10 \mathrm{mM} \mathrm{KNO}_{3}$ was added to the medium for anaerobic growth and the reduction of nitrate was monitored by using an ion chromatograph (model 790 personal IC;

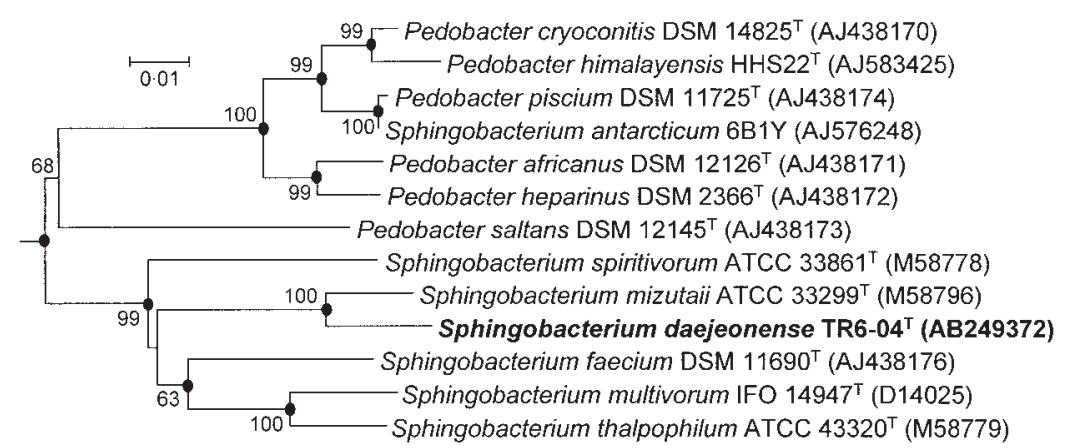

Fig. 1. Neighbour-joining tree showing the phylogenetic positions of strain TR6-04 among strains of the genera Sphingobacterium and Pedobacter. GenBank accession numbers are shown in parentheses. Bootstrap values (expressed as percentages of 1000 replications) greater than $50 \%$ are shown at branch points. Dots indicate that the corresponding nodes were also recovered in the tree generated with the maximumparsimony algorithm. Bar, 0.01 substitutions per nucleotide position. 
Metrohm) equipped with a conductivity detector and an anion-exchange column (Metrosep Anion Supp 4; Metrohm). Degradation of DNA (using DNase agar from Scharlau, supplemented with $1 \mathrm{M} \mathrm{HCl}$ ), casein, chitin and starch (Atlas, 1993), lipid (Kouker \& Jaeger, 1987) and xylan and cellulose (Ten et al., 2004) was also investigated; reactions were read after 5 days. Growth at different temperatures $\left(4,15,25,30,37\right.$ and $\left.42^{\circ} \mathrm{C}\right)$ and various $\mathrm{pH}$ values ( $\mathrm{pH} 5 \cdot 0-10 \cdot 0$ at intervals of $0.5 \mathrm{pH}$ units) was assessed after 5 days incubation. Salt tolerance was tested on R2A medium supplemented with $1-10 \%(w / v) ~ \mathrm{NaCl}$ after 5 days incubation. Growth on nutrient agar, trypticase soy agar (TSA; Difco) and MacConkey agar was also evaluated at $30^{\circ} \mathrm{C}$.
Strain TR6- $04^{\mathrm{T}}$ is a Gram-negative, non-spore-forming, non-motile and rod-shaped bacterium. After 3 days incubation at $30^{\circ} \mathrm{C}$, colonies on R2A agar medium are round, slightly yellowish, convex and $1.0-2.0 \mathrm{~mm}$ in diameter. On R2A agar, the optimal growth temperature for TR6$04^{\mathrm{T}}$ was $30^{\circ} \mathrm{C}$. Strain TR6- $04^{\mathrm{T}}$ was able to grow at $42^{\circ} \mathrm{C}$, but not at 10 or $45^{\circ} \mathrm{C}$. The $\mathrm{pH}$ growth range was between $\mathrm{pH} 5.0$ and $9 \cdot 0$, with an optimum between $\mathrm{pH} 6.5$ and $7 \cdot 0$. Growth occurred in the absence of $\mathrm{NaCl}$ and in the presence of $5.0 \%(\mathrm{w} / \mathrm{v}) \mathrm{NaCl}$, but not $7 \%(\mathrm{w} / \mathrm{v}) \mathrm{NaCl}$. Phenotypic and chemotaxonomic characteristics that differentiate strain TR6- $04^{\mathrm{T}}$ from related Sphingobacterium species are listed in Table 1. In contrast to all other Sphingobacterium species, strain TR6-04 ${ }^{\mathrm{T}}$ assimilates L-xylose, does not

Table 1. Differential phenotypic characteristics of strain TR6-0 $4^{\top}$ and related type strains of Sphingobacterium species

Strains: 1, S. daejeonense sp. nov. TR6 $-04^{\mathrm{T}}$ (data from the present study); 2, S. spiritivorum NBRC $14948^{\mathrm{T}}$; 3, S. multivorum NBRC $14947^{\mathrm{T}}$; 4, S. mizutaii NBRC $14946^{\mathrm{T}}$; 5, S. thalpophilum NBRC $14963^{\mathrm{T}}$; 6, S. faecium NBRC $15299^{\mathrm{T}}$ (data in columns 2-6 taken from Takeuchi \& Yokota, 1992; Steyn et al., 1998); 7, S. antarcticum MTCC $675^{\mathrm{T}}$ (data from Shivaji et al., 1992). All strains are positive for aerobic growth at $30^{\circ} \mathrm{C}$, catalase and oxidase activities, assimilation of D-glucose, D-mannose, D-raffinose, D-fructose, L-lactose, D-maltose and sucrose and acid production from D-glucose. All strains are negative for Gram staining, sporulation, indole production, motility, assimilation of acetate and acid production from inositol. With the exception of S. antarcticum MTCC $675^{\mathrm{T}}$, all strains are positive for assimilation of D-cellobiose, D-trehalose, amygdalin, $N$-acetyl-D-glucosamine and salicin and acid production from D-melibiose and amygdalin, and all strains are negative for assimilation of D-fucose, L-sorbose, gluconate, dulcitol, xylitol, propionate, valerate, caprate, phenylacetate, benzoate, 3-hydroxybenzoate, maleate, DL-lactate, glutarate, tartrate, itaconate, adipate, suberate, oxalate, glycine, L-alanine, L-leucine and L-valine (data are not reported for S. antarcticum). +, Positive; -, negative; v, variable; ND, no data available.

\begin{tabular}{|c|c|c|c|c|c|c|c|}
\hline Characteristic & 1 & 2 & 3 & 4 & 5 & 6 & 7 \\
\hline \multicolumn{8}{|l|}{ Growth at: } \\
\hline $5^{\circ} \mathrm{C}$ & - & - & - & - & - & + & + \\
\hline $42{ }^{\circ} \mathrm{C}$ & + & - & - & - & + & - & - \\
\hline \multicolumn{8}{|l|}{ Hydrolysis of: } \\
\hline DNA & - & + & + & + & - & + & $\mathrm{ND}$ \\
\hline Starch & - & + & + & + & + & + & - \\
\hline Aesculin & - & + & + & + & + & + & + \\
\hline Gelatin & - & - & - & - & - & - & + \\
\hline Urease & - & + & + & + & + & + & + \\
\hline \multicolumn{8}{|l|}{ Assimilation of: } \\
\hline L-Rhamnose & - & + & + & - & + & + & + \\
\hline L-Arabinose & - & - & + & $\mathrm{V}$ & + & + & + \\
\hline D-Mannitol & - & + & - & - & - & - & + \\
\hline D-Melibiose & + & + & + & + & + & + & - \\
\hline Glycerol & - & $\mathrm{V}$ & - & - & + & + & + \\
\hline Inulin & - & $\mathrm{V}$ & $\mathrm{V}$ & - & + & + & + \\
\hline Pyruvate & - & - & - & V & - & - & + \\
\hline L-Glutamate & - & - & + & + & - & + & + \\
\hline \multicolumn{8}{|l|}{ Acid production from: } \\
\hline L-Rhamnose & - & - & $\mathrm{V}$ & - & + & - & - \\
\hline L-Arabinose & - & - & + & + & + & + & - \\
\hline Sucrose & - & + & + & + & + & + & - \\
\hline DNA $G+C$ content $(\mathrm{mol} \%)$ & $38 \cdot 7$ & $39 \cdot 0$ & $39 \cdot 9-40 \cdot 5$ & $39 \cdot 3-40 \cdot 0$ & $44 \cdot 0-44 \cdot 2$ & $37 \cdot 3$ & $39 \cdot 3$ \\
\hline
\end{tabular}


hydrolyse aesculin and does not produce urease. Strain TR6$04^{\mathrm{T}}$ could be distinguished from S. antarcticum MTCC $675^{\mathrm{T}}$ on the basis of its inability to assimilate L-rhamnose, L-arabinose, D-ribose, pyruvate, formate, DL-3-hydroxybutyrate, lactate, malate, succinate, inositol, D-mannitol, Dsorbitol, glycerol and L-glutamate, to produce gelatinase and hydrogen sulphide, to grow at temperatures below $15^{\circ} \mathrm{C}$ and to grow on MacConkey agar.

For the measurement of $\mathrm{G}+\mathrm{C}$ content of the chromosomal DNA, genomic DNA was extracted and purified as described by Moore (1995) and was then enzymically degraded into nucleosides. $\mathrm{G}+\mathrm{C}$ content was determined as described by Mesbah et al. (1989) using a reverse-phase HPLC. Isoprenoid quinones were extracted with chloroform/ methanol $(2: 1, \mathrm{v} / \mathrm{v})$, evaporated under vacuum and reextracted in $\mathrm{n}$-hexane/water $(1: 1, \mathrm{v} / \mathrm{v})$. The crude $\mathrm{n}$-hexane quinone solution was then purified using silica Sep-Pak Vac cartridges (Waters) and subsequently analysed by HPLC, as described previously (Hiraishi et al., 1996).

Cellular fatty acid profiles were determined for strains grown on TSA for 2 days. The cellular fatty acids were saponified, methylated and extracted according to the protocol of the Sherlock Microbial Identification System (MIDI) and then analysed by a gas chromatograph (Hewlett Packard 6890) and identified by the Microbial Identification software package (Sasser, 1990). The cellular fatty acid profiles of strain TR6- $04^{\mathrm{T}}$ and related Sphingobacterium species are presented in Table 2. Strain TR6-0 $4^{\mathrm{T}}$ contained large amounts of iso-branched and iso-branched hydroxy fatty acids; the major components were iso- $\mathrm{C}_{15: 0}$, iso- $\mathrm{C}_{17: 0}$ $3-\mathrm{OH}$ and summed feature 4 (iso- $\mathrm{C}_{15: 0} 2-\mathrm{OH}$ and/or $\mathrm{C}_{16: 1} \omega 7 c$ ), typical of members of the genus Sphingobacterium (Takeuchi \& Yokota, 1992; Steyn et al., 1998). Some qualitative and quantitative differences in fatty acid

Table 2. Fatty acid compositions of strain $\mathrm{TR} 6-04^{\top}$ and related Sphingobacterium species

Strains: 1, S. daejeonense TR6-04 ${ }^{\mathrm{T}}$ (data from the present study); 2, S. spiritivorum NBRC $14948^{\mathrm{T}} ; 3, S$. multivorum NBRC $14947^{\mathrm{T}}$; 4, S. mizutaii NBRC $14946^{\mathrm{T}}$; 5, S. thalpophilum NBRC $14963^{\mathrm{T}}$; 6, S. faecium NBRC $15299^{\mathrm{T}}$ (data in columns 2-6 were taken from Steyn et al., 1998); 7. S. antarcticum MTCC $675^{\mathrm{T}}$ (data from Shivaji et al., 1992). Values are percentages of total fatty acids. +, Fatty acid detected but its content was not reported; tr, trace $(<1.0 \%)$; -, not detected; ECL, equivalent chain-length (for unknown fatty acids with no name listed in the peak library file of the MIDI system which therefore cannot be identified). Major components $(>15 \%)$ are indicated in bold.

\begin{tabular}{|c|c|c|c|c|c|c|c|}
\hline Fatty acid & 1 & 2 & 3 & 4 & 5 & 6 & 7 \\
\hline \multicolumn{8}{|c|}{ Straight-chain saturated } \\
\hline $\mathrm{C}_{14: 0}$ & - & $1 \cdot 0$ & $2 \cdot 7$ & $\operatorname{tr}$ & $3 \cdot 2$ & $\operatorname{tr}$ & + \\
\hline $\mathrm{C}_{16: 0}$ & $3 \cdot 4$ & $3 \cdot 5$ & $7 \cdot 8$ & $\operatorname{tr}$ & $6 \cdot 0$ & $4 \cdot 5$ & + \\
\hline $\mathrm{C}_{16: 0} 2-\mathrm{OH}$ & - & - & $\operatorname{tr}$ & - & $3 \cdot 2$ & - & - \\
\hline $\mathrm{C}_{16: 0} 3-\mathrm{OH}$ & - & $2 \cdot 7$ & $5 \cdot 3$ & $\operatorname{tr}$ & $6 \cdot 3$ & $2 \cdot 1$ & - \\
\hline \multicolumn{8}{|l|}{ Branched saturated } \\
\hline iso- $\mathrm{C}_{15: 0}$ & $45 \cdot 6$ & $30 \cdot 1$ & $22 \cdot 2$ & $30 \cdot 0$ & $17 \cdot 7$ & $24 \cdot 6$ & $29 \cdot 0$ \\
\hline iso- $\mathrm{C}_{17: 0}$ & $\operatorname{tr}$ & - & - & - & - & - & - \\
\hline iso- $\mathrm{C}_{15: 0} 2-\mathrm{OH}$ & $-^{\star}$ & $21 \cdot 5$ & $17 \cdot 4$ & $25 \cdot 6$ & $24 \cdot 6$ & $15 \cdot 9$ & $\operatorname{tr}$ \\
\hline iso- $\mathrm{C}_{15: 0} 3-\mathrm{OH}$ & $1 \cdot 5$ & $2 \cdot 2$ & $3 \cdot 2$ & $3 \cdot 0$ & $4 \cdot 3$ & $3 \cdot 7$ & $\operatorname{tr}$ \\
\hline iso- $\mathrm{C}_{17: 0} 3-\mathrm{OH}$ & $16 \cdot 6$ & $12 \cdot 5$ & $7 \cdot 1$ & $22 \cdot 1$ & $10 \cdot 0$ & $10 \cdot 0$ & $\operatorname{tr}$ \\
\hline anteiso- $\mathrm{C}_{15: 0}$ & $2 \cdot 6$ & $\operatorname{tr}$ & - & $\operatorname{tr}$ & - & $\operatorname{tr}$ & - \\
\hline $\mathrm{C}_{16: 0} \quad 10$-methyl & - & - & - & - & - & $1 \cdot 4$ & - \\
\hline Summed feature $4 \dagger$ & $23 \cdot 8$ & - & - & - & - & - & - \\
\hline \multicolumn{8}{|l|}{ Monounsaturated } \\
\hline iso- $\mathrm{C}_{15: 1} \mathrm{G}$ & $\operatorname{tr}$ & - & - & - & - & - & - \\
\hline $\mathrm{C}_{16: 1} \omega 5 c$ & $\operatorname{tr}$ & $\operatorname{tr}$ & - & $\operatorname{tr}$ & - & $1 \cdot 5$ & - \\
\hline $\mathrm{C}_{16: 1} \omega 7 c$ & $-^{*}$ & $21 \cdot 1$ & $31 \cdot 6$ & $9 \cdot 5$ & $23 \cdot 2$ & $32 \cdot 2$ & $56 \cdot 0$ \\
\hline iso- $\mathrm{C}_{17: 1} \omega 9 c$ & $2 \cdot 9$ & $1 \cdot 7$ & $\operatorname{tr}$ & $3 \cdot 7$ & - & - & - \\
\hline $\mathrm{C}_{17: 1}$ & - & - & - & - & - & - & + \\
\hline \multicolumn{8}{|l|}{ Unknown } \\
\hline ECL $13 \cdot 566$ & $1 \cdot 0$ & $\operatorname{tr}$ & - & $1 \cdot 3$ & $1 \cdot 4$ & $\operatorname{tr}$ & - \\
\hline ECL $16 \cdot 580$ & $\operatorname{tr}$ & $\operatorname{tr}$ & $\operatorname{tr}$ & $\operatorname{tr}$ & - & $\operatorname{tr}$ & - \\
\hline
\end{tabular}

${ }^{*}$ Components included in summed feature 4 .

$†$ Summed features represent groups of two or three fatty acids that can not be separated by GLC with the MIDI system. Summed feature 4 contains iso- $\mathrm{C}_{15: 0} 2-\mathrm{OH}$ and/or $\mathrm{C}_{16: 1} \omega 7 c$. 
contents could be observed between strain TR6- $04^{\mathrm{T}}$ and the phylogenetically closest relative, S. mizutaii ATCC $33299^{\mathrm{T}}$. In comparison with this strain, strain TR6- $04^{\mathrm{T}}$ contained larger amounts of iso- $\mathrm{C}_{15: 0}$ and smaller amounts of iso- $\mathrm{C}_{15: 0} 2-\mathrm{OH}$ and/or $\mathrm{C}_{16: 1} \omega 7_{c}$ and it did not contain $\mathrm{C}_{14: 0}$ or $\mathrm{C}_{16: 0} 3-\mathrm{OH}$. The $\mathrm{G}+\mathrm{C}$ content of genomic DNA for members of the genus Sphingobacterium ranges from $37 \cdot 3 \mathrm{~mol} \%$ (reported for S. faecium) to $44 \cdot 2 \mathrm{~mol} \%$ (reported for S. thalpophilum) (Takeuchi \& Yokota, 1992; Steyn et al., 1998). The $\mathrm{G}+\mathrm{C}$ content of the DNA of strain TR6- $04^{\mathrm{T}}$ was $38 \cdot 7 \mathrm{~mol} \%$ and falls within this range.

All of the characteristics determined for strain TR6- $04^{\mathrm{T}}$ are in accordance with those of the genus Sphingobacterium. On the basis of phylogenetic distance from established Sphingobacterium species, also indicated by relatively low $16 \mathrm{~S}$ rRNA gene sequence similarities $(<97 \%)$ and the combination of unique phenotypic characteristics, it is demonstrable that TR6- $04^{\mathrm{T}}$ is not affiliated with any species of this genus. Therefore, on the basis of the data presented, strain TR6- $04^{\mathrm{T}}$ should be placed in the genus Sphingobacterium as the type strain of a novel species, for which the name Sphingobacterium daejeonense sp. nov. is proposed.

\section{Description of Sphingobacterium daejeonense sp. nov.}

Sphingobacterium daejeonense (dae.jeon.en'se. N.L. neut. adj. daejeonense pertaining to Daejeon, a city in Korea, where the type strain was isolated).

Cell are Gram-negative, strictly aerobic, non-spore-forming, non-motile and rod-shaped $(0 \cdot 5-1 \cdot 0 \mu \mathrm{m}$ wide and $1 \cdot 2-$ $1.8 \mu \mathrm{m}$ long). After 3 days incubation at $30^{\circ} \mathrm{C}$ on $\mathrm{R} 2 \mathrm{~A}$, colonies are $1-2 \mathrm{~mm}$ in diameter, smooth, convex, round and slightly yellowish. Growth occurs between 15 and $42^{\circ} \mathrm{C}$; the optimum temperature for growth is $30^{\circ} \mathrm{C}$. The $\mathrm{pH}$ range for growth is $\mathrm{pH} 5 \cdot 0-9 \cdot 0$, with an optimum between $\mathrm{pH} 6 \cdot 5$ and $7 \cdot 0$. Tolerates $5 \%(\mathrm{w} / \mathrm{v}) \mathrm{NaCl}$, but not $7 \%$. Growth occurs on TSA, but not on MacConkey agar. Positive for catalase and oxidase. Negative for hydrolysis of chitin, starch, cellulose, DNA, xylan, casein and aesculin. The following substrates are utilized for growth: D-glucose, Dgalactose, D-mannose, D-fructose, D-arabinose, D-lyxose, D-xylose, L-xylose, $N$-acetyl-D-glucosamine, salicin, Dcellobiose, D-lactose, D-maltose, D-melibiose, sucrose, Dtrehalose, D-raffinose, D-adonitol and amygdalin. The following substrates are not utilized for growth: D-fucose, ethanol, L-rhamnose, L-sorbose, L-arabinose, D-ribose, pyruvate, formate, acetate, propionate, DL-3-hydroxybutyrate, valerate, caprate, maleate, fumarate, phenylacetate, benzoate, 3-hydroxybenzoate, 4-hydroxybenzoate, citrate, lactate, malate, malonate, succinate, glutarate, tartrate, itaconate, adipate, suberate, oxalate, gluconate, dulcitol, inositol, D-mannitol, D-sorbitol, xylitol, glycerol, methanol, glycogen, inulin, dextran, L-alanine, L-arginine, L-asparagine, L-aspartic acid, L-cysteine, L-glutamic acid, L-glutamine, L-histidine, glycine, L-isoleucine, L-leucine, Llysine, L-methionine, L-phenylalanine, L-proline, L-serine,
L-threonine, L-tryptophan, L-tyrosine and L-valine. In API $20 \mathrm{E}$ tests, $\beta$-galactosidase and the Voges-Proskauer test are positive; tests for arginine dihydrolase, lysine decarboxylase, ornithine decarboxylase, tryptophan deaminase, urease, gelatinase, hydrogen sulphide and indole production are all negative. Acid is produced from D-glucose, D-melibiose and amygdalin, but not from L-arabinose, D-mannitol, inositol, D-sorbitol, L-rhamnose or sucrose. MK-7 is the predominant menaquinone, and major fatty acids are iso$\mathrm{C}_{15: 0}$, summed feature 4 (iso- $\mathrm{C}_{15: 0} 2-\mathrm{OH}$ and/or $\mathrm{C}_{16: 1} \omega 7 c$ ) and iso- $\mathrm{C}_{17: 0} 3-\mathrm{OH}$. The $\mathrm{G}+\mathrm{C}$ content of genomic DNA of the type strain is $38.7 \mathrm{~mol} \%$ (as determined by HPLC).

The type strain, TR6-04 $4^{\mathrm{T}} \quad\left(=\right.$ KCTC $12579^{\mathrm{T}}=\mathrm{LMG}$ $23402^{\mathrm{T}}=$ CCUG $52468^{\mathrm{T}}$ ), was isolated from compost that was collected near Daejeon city in South Korea.

\section{Acknowledgements}

This work was supported by the Brain Pool Program (grant 031-4-17) funded by the Ministry of Science and Technology and by the 21C Frontier Microbial Genomics and Application Center Program, Ministry of Science \& Technology (grant MG05-0101-4-0), Republic of Korea.

\section{References}

Atlas, R. M. (1993). Handbook of Microbiological Media. Edited by L. C. Parks. Boca Raton, FL: CRC Press.

Buck, J. D. (1982). Nonstaining (KOH) method for determination of Gram reactions of marine bacteria. Appl Environ Microbiol 44, 992-993.

Euzéby, J. P. (1998). Taxonomic note: necessary correction of specific and subspecific epithets according to Rules $12 \mathrm{c}$ and $13 \mathrm{~b}$ of the International Code of Nomenclature of Bacteria (1990 Revision). Int J Syst Bacteriol 48, 1073-1075.

Felsenstein, J. (1985). Confidence limit on phylogenies: an approach using the bootstrap. Evolution 39, 783-791.

Fitch, W. M. (1972). Toward defining the course of evolution: minimum change for a specific tree topology. Syst Zool 20, 406-416.

Hall, T. A. (1999). BIOEDIT: a user-friendly biological sequence alignment editor and analysis program for Windows 95/98/NT. Nucleic Acids Symp Ser 41, 95-98.

Hiraishi, A., Ueda, Y., Ishihara, J. \& Mori, T. (1996). Comparative lipoquinone analysis of influent sewage and activated sludge by highperformance liquid chromatography and photodiode array detection. $J$ Gen Appl Microbiol 42, 457-469.

Holmes, B., Owen, R. J. \& Weaver, R. E. (1981). Flavobacterium multivorum, a new species isolated from human clinical specimens and previously known as group IIk, biotype 2. Int J Syst Bacteriol 31, 21-34.

Holmes, B., Owen, R. J. \& Hollis, D. G. (1982). Flavobacterium spiritivorum, a new species isolated from human clinical specimens. Int J Syst Bacteriol 32, 157-165.

Holmes, B., Weaver, R. E., Steigerwalt, A. G. \& Brenner, D. J. (1988). A taxonomic study of Flavobacterium spiritivorum and Sphingobacterium mizutae: proposal of Flavobacterium yabuuchiae sp. nov. and Flavobacterium mizutaii comb. nov. Int J Syst Bacteriol 38, 348-353. 
Keswani, J. \& Whitman, W. B. (2001). Relationship of 16S rRNA sequence similarity to DNA hybridization in prokaryotes. Int $J$ Syst Evol Microbiol 51, 667-678.

Kim, M. K., Im, W.-T., Ohta, H., Lee, M. \& Lee, S.-T. (2005). Sphingopyxis granuli sp. nov., a $\beta$-glucosidase producing bacterium in the family Sphingomonadaceae in $\alpha-4$ subclass of the Proteobacteria. J Microbiol 43, 152-157.

Kimura, M. (1983). The Neutral Theory of Molecular Evolution. Cambridge: Cambridge University Press.

Kouker, G. \& Jaeger, K.-E. (1987). Specific and sensitive plate assay for bacterial lipases. Appl Environ Microbiol 53, 211-213.

Kumar, S., Tamura, K. \& Nei, M. (2004). MEGA3: integrated software for molecular evolutionary genetics analysis and sequence alignment. Brief Bioinform 5, 150-163.

Mesbah, M., Premachandran, U. \& Whitman, W. B. (1989). Precise measurement of the $\mathrm{G}+\mathrm{C}$ content of deoxyribonucleic acid by highperformance liquid chromatography. Int J Syst Bacteriol 39, 159-167.

Moore, D. D. (1995). Preparation and analysis of DNA. In Current Protocols in Molecular Biology, pp. 2.4.1-2.4.2. Edited by F. W. Ausubel, R. Brent, R. E. Kingston, D. D. Moore, J. G. Seidman, J. A. Smith \& K. Struhl. New York: Wiley.

Saitou, N. \& Nei, M. (1987). The neighbor-joining method: a new method for reconstructing phylogenetic trees. Mol Biol Evol 4, 406-425.

Sasser, M. (1990). Identification of bacteria by gas chromatography of cellular fatty acids. Technical Note 101. Newark, DE: MIDI Inc.

Shivaji, S., Ray, M. K., Rao, N. S., Saisree, L., Jagannadham, M. V., Kumar, G. S., Reddy, G. S. N. \& Bhargava, P. M. (1992). Sphingobacterium antarcticus sp. nov., a psychrotrophic bacterium from the soils of Schirmacher Oasis, Antarctica. Int J Syst Bacteriol 42, 102-106.

Stackebrandt, E. \& Goebel, B. M. (1994). Taxonomic note: a place for DNA-DNA reassociation and 16S rRNA sequence analysis in the present species definition in bacteriology. Int J Syst Bacteriol 44, 846-849.

Steyn, P. L., Segers, P., Vancanneyt, M., Sandra, P., Kersters, K. \& Joubert, J. J. (1998). Classification of heparinolytic bacteria into a new genus, Pedobacter, comprising four species: Pedobacter heparinus comb. nov., Pedobacter piscium comb. nov., Pedobacter africanus sp. nov. and Pedobacter saltans sp. nov. Proposal of the family Sphingobacteriaceae fam. nov. Int J Syst Bacteriol 48, 165-177.

Takeuchi, M. \& Yokota, A. (1992). Proposals of Sphingobacterium faecium sp. nov., Sphingobacterium piscium sp. nov., Sphingobacterium heparinum comb. nov., Sphingobacterium thalpophilum comb. nov. and two genospecies of the genus Sphingobacterium, and synonymy of Flavobacterium yabuuchiae and Sphingobacterium spiritivorum. J Gen Appl Microbiol 38, 465-482.

Ten, L. N., Im, W.-T., Kim, M.-K., Kang, M.-S. \& Lee, S.-T. (2004), Development of a plate technique for screening of polysaccharidedegrading microorganisms by using a mixture of insoluble chromogenic substrates. J Microbiol Methods 56, 375-382.

Thompson, J. D., Gibson, T. J., Plewniak, F., Jeanmougin, F. \& Higgins, D. G. (1997). The CLUSTAL_X windows interface: flexible strategies for multiple sequence alignment aided by quality analysis tools. Nucleic Acids Res 25, 4876-4882.

Tschech, A. \& Pfennig, N. (1984). Growth yield increase linked to caffeate reduction in Acetobacterium woodii. Arch Microbiol 137, 163-167.

Wayne, L. G., Brenner, D. J., Colwell, R. R. \& 9 other authors (1987). International Committee on Systematic Bacteriology. Report of the ad hoc committee on reconciliation of approaches to bacterial systematics. Int J Syst Bacteriol 37, 463-464.

Widdel, F. \& Bak, F. (1992). Gram-negative mesophilic sulfate reducing bacteria. In The Prokaryotes, 2nd edn, pp. 3352-3378. Edited by A. Balows, H. G. Trüper, M. Dworkin, W. Harder \& K. H. Schleifer. New York: Springer.

Widdel, F., Kohring, G. \& Mayer, F. (1983). Studies in dissimilatory sulfate-reducing bacteria that decompose fatty acids. III. Characterization of the filamentous gliding Desulfonema limicola gen. nov. sp. nov., and Desulfonema magnum sp. nov. Arch Microbiol 134, 286-294.

Yabuuchi, E., Kaneko, T., Yano, I., Moss, C. W. \& Miyoshi, N. (1983). Sphingobacterium gen. nov., Sphingobacterium spiritivorum comb. nov., Sphingobacterium multivorum comb. nov., Sphingobacterium mizutae sp. nov., and Flavobacterium indologenes sp. nov. glucosenonfermenting gram-negative rods in CDC groups IIk-2 and IIb. Int J Syst Bacteriol 33, 580-598. 